DOI: https://doi.org/10.32839/2304-5809/2019-10-74-79

УДК 656.13

Процик О.П., Шатликов Д., Тарасенко С.В., Полегенько А.Ю. Національний транспортний університет

\title{
АНАЛІЗ СТАНУ ТА ПЕРСПЕКТИВИ РОЗВИТКУ РИНКУ ТРАНСПОРТНИХ ПОСЛУГ В УКРАЇНІ
}

\begin{abstract}
Анотація. Проведено аналіз сучасного ринку транспортних послуг та сконцентровано увагу на автомобільних, як найбільш розповсюдженим. В роботі зазначено, що сьогодні транспортні послуги - це галузь економіки, яка динамічно розвивається, в більшій ступені не потребує державного фрінансування і $€$ однією з найпривабливіших галузей економіки для інвестицій. Приділено увагу розвитку міжнародних автомобільних перевезень, включаючи транспортну інфраструктуру, що розвивається. Виділено основні проблеми та наведено шляхи покращення системи міжнародних автомобільних перевезень. Зазначені проблеми автомобільного транспорту, що виникають в умовах загострення економічної ситуації в країні, потрібно враховувати при реформуванні транспортного сектору економіки.
\end{abstract}

Ключові слова: транспортні послуги, автомобільні перевезення, транспортні підприемства.

\section{Protsyk Alexander, Dovnar Shatlikov, Tarasenko Svetlana, Polegenko Anastasia National University of Transport}

\section{CONDITION ANALYSIS AND PROSPECTS OF TRANSPORT MARKET DEVELOPMENT IN UKRAINE}

Summary. The analysis of the modern market of transport services is carried out and the attention is focused on automobile, as the most widespread. The paper states that today transport services are a rapidly developing economy that is not in need of public funding and is one of the most attractive sectors of the economy for investment; not only direct delivery of goods, but also the provision of a full range of transport and logistics services. In the article it is noted that the national scientists pays considerable attention to the issues of analysis of the state and finding ways of development of the market of transport services. Attention is paid to the development of international road haulage, including developing transport infrastructure. In the article it is noted that the national scientists pays considerable attention to the issues of analysis of the state and finding ways of development of the market of transport services. Attention is paid to the development of international road haulage, including developing transport infrastructure. Transport corridors also play a significant role in the development of international trade and provide an opportunity to expand and provide transport services according to European standards. he main problems of international road transport, such as environmental pollution, are highlighted; accident rate; high costs; poor condition of the road complex; technical condition of cars; low skills of drivers and ways to improve the system of international road haulage. Ways to solve problems and improve the system of international road transport are: improving the system of management and control of international traffic; application of a rigid licensing system; ensuring quality conditions for market entry; creation of a single integrated road safety management system; public financing; raising funds of insurance organizations; availability of qualified personnel; application of rational methods of transportation. These problems of road transport, which arise in the conditions of aggravation of the economic situation in the country, should be taken into account when reforming the transport sector of the economy.

Keywords: transport services, road transport, transport enterprise.

$\Pi^{\circ}$ остановка проблеми. Розвиток транспортних послуг, що надається замовникам вимагає враховувати всі існуючі проблеми як в транспортній галузі в цілому, так і в секторі надання послуг. Для покращення існуючого стану на ринку транспортних послуг необхідно провести всебічний аналіз ринку, в тому числі виявлення проблем, що стримують його розвиток.

Аналіз останніх досліджень і публікацій. Питанням підвищення ефективності транспортного процесу присвячені наукові роботи багатьох вітчизняних та зарубіжних вчених. Ними запропоновано різні підходи для вирішення поставленої задачі, але в більшості робіт вирішуються питання окремих галузей економіки чи ТТСДВ, що в багатьох випадках обмежуе сферу застосування даних методик для інших вантажів чи умов. Запропонована методика дає можливість визначити «вузькі» місця у системі доставки та вжити необхідних заходів відповідно до наявних ресурсів, та прийнятих критеріїв едективності.

Загальні проблеми управління на транспорті та організації перевезень висвітлені в дослідженнях Воркута А.М., Костюченко Л.М., Коваленко В.М., Вельможина Л.В., Гудкова В.А., Міротіна Л.Б., Кунди Н.Т., Коцюка О.Я. та інших науковців. Окремі аспекти управління на транспорті вивчалися рядом вчених зокрема, технічні аспекти створення моделей і алгоритмів побудови логістичних ланцюгів на транспорті відображено у дослідженнях Дмитриченко М.Ф., Левковця П.Р., Ткаченко А.М., Ігнатенко О.С., Зайонцика Л.Г. та інші науковці.

Мета статті. Головною метою даної статті $\epsilon$ визначення перспектив розвитку галузі надання транспортних послуг, шляхом аналізу його сучасного стану та визначення перспективних шляхів розвитку. 


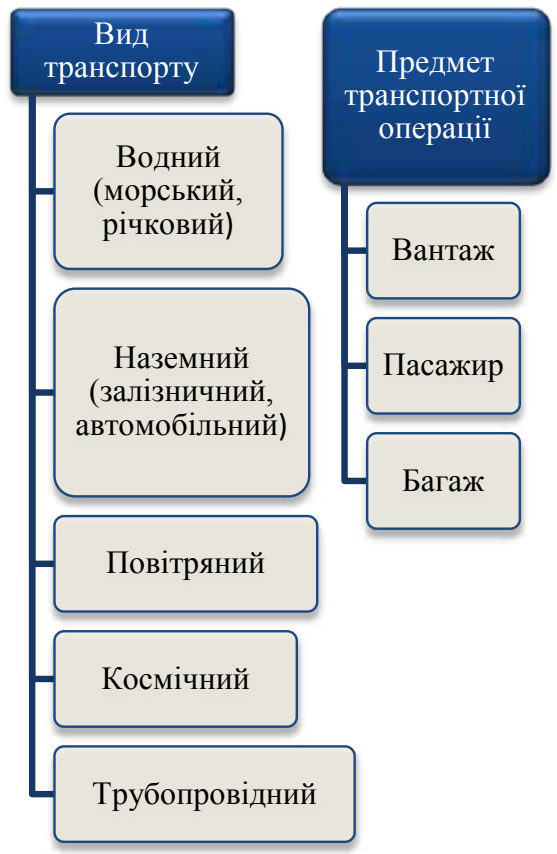

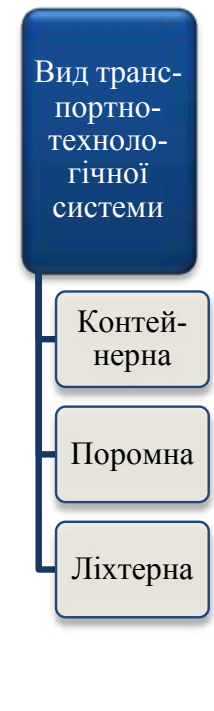

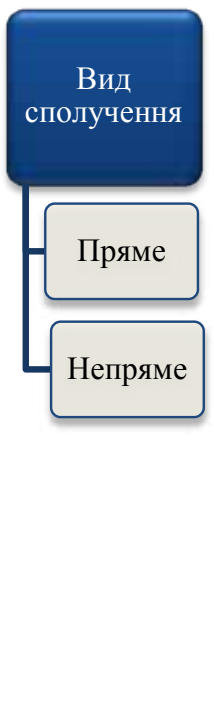

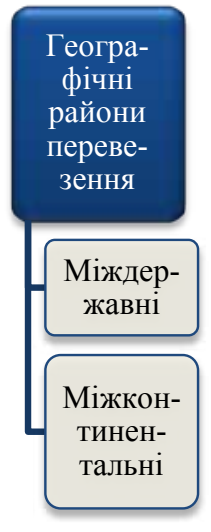

Рис. 1. Класифікація послуг видів транспорту

Виклад основного матеріалу. Міжнародний транспорт - це послуги всіх видів транспорту переміщення предмета транспортної операції, що надаються резидентами одніеї країни резидентам іншої країни. Спектр транспортних послуг широкий (рис. 1).

Транспортні послуги розрізняються в залежності від:

- виду транспорту: водний (морський і річковий); наземний (залізничний і автомобільний); повітряний (авіаційний); трубопровідний;

- предмета транспортної операції (вантаж, пасажир, багаж);

- транспортної характеристики товару: наливної (нафрта і продукти ї̈ переробки, рослинні олії) та сухої (навалювальні (вугілля, руда), насипні (зерно, цемент, фросфрати) і генеральні (штучні));

- періодичності перевезення (регулярні і нерегулярні);

- порядку проходження кордону (перевантажувальні і безвантажні);

- виду транспортно-технологічної системи (контейнерна, поромна та ін.);

- виду повідомлення (пряме, непряме та ін.).

Транспорт України $є$ інвестиційно привабливим: п'ята частина від загальних обсягів інвестицій в основний капітал припадає на долю транспорту. При цьому 80\% інвестицій у транспортно-дорожній комплекс здійснено за рахунок власних коштів підприемств галузі.

Згідно К.В. Масляевої, «транспортний ринок» - це сорера економічних зв'язків, які виникають між суб'єктами ринкових відносин із приводу надання послуг шляхом погодження ціни, і регулюються державою. До суб'єктів відносяться споживачі послуг - вантажовласники та вантажовідправники, а також ті, хто надають ці послуги - перевізники та експедитори. Важливу роль серед учасників ринку транспортних послуг відіграють органи державної влади та місцевого самоврядування, які здійснюють функції державного регулювання та контролю за учас- никами ринку транспортних послуг. Обєєтом купівлі-продажу на ринку транспортних послуг є транспортні послуги - це перш за все послуги з перевезення вантажу за встановленими маршрутами. Сьогодні транспортні послуги - це галузь економіки, яка динамічно розвивається.

Наразі широко використовуються транспортні коридори, що поєднують на визначених напрямках відразу кілька видів транспорту для перевезень через територію ряду країн з відповідним фрінансовим і правовим забезпеченням.

На обсяги міжнародної торгівлі можуть істотно впливати транспортні витрати. Транспортні витрати (витрати на доставку товару від виробника до споживача, що включають вартість фррахту, страхування, навантаження/розвантаження, упакування/розпакування й інші супутні витрати) бувають настільки великими, що роблять експорт і імпорт товарів невигідними, тобто перетворюють товари з «ринкових» у «неринкові». Це призводить до зниження обсягів торгівлі, рівня спеціалізації країн, розмірів виграшу від торгівлі.

Стала ще більш помітною тенденція українських транспортних компаній до приведення своїх послуг у відповідність 3 европейськими та міжнародними нормами. Крім того, все більша кількість служб доставки і транспортних компаній починають приділяти пильну увагу не лише безпосередній організації перевезення вантажів, але й наданню цілого комплексу транспортно-логістичних послуг.

Автомобільні перевезення - найбільш популярний вид перевезення вантажів (рис. 2).

Сучасна діяльність різних організацій неможлива без тісної співпраці з транспортними компаніями. Для багатьох 3 них своєчасна та якісна доставка вантажів є одним з найбільш важливих фракторів, що впливають на стабільність і розвиток. Для приватних замовників належний рівень надання транспортних послуг не менш важливий, оскільки він $є$ запорукою спокою і впевненості в дбайливості перевезення майна. 


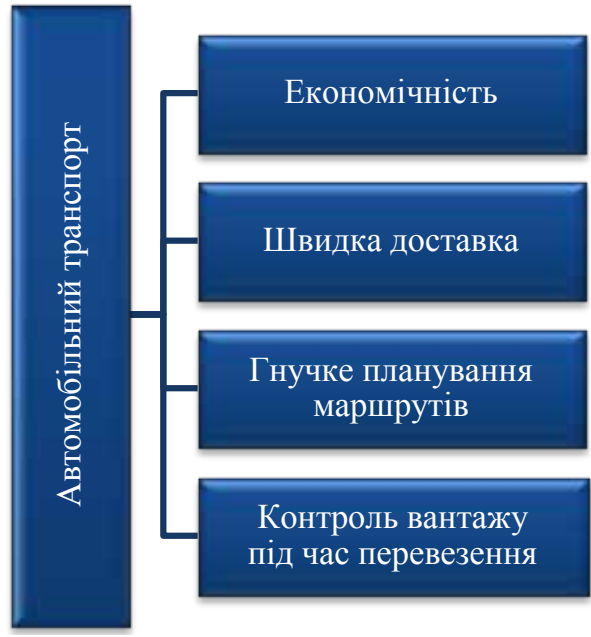

Рис. 2. Переваги автомобільного транспорту

Тому інтерес до представників сфери вантажоперевезень зростае з кожним роком.

Транспортні підприемства надають своїм кліентам все більш широкий спектр послуг, гарантуючи при цьому їх якість. Шлях вантажу починається 3 розробки концепції та оптимального маршруту його доставки, підготовки документації та розрахунку вартості перевезення. При цьому визначаються необхідні транспортні та вантажні засоби, оформляються необхідні дозволи, виконуеться моніторинг руху вантажу з моменту початку відвантаження до моменту доставки його до місця призначення.

Незважаючи на визнання транспорту пріоритетною сферою діяльності, яка повинна підтримуватися державою, фрінансуватися і розвиватися, щоб відповідати міжнародним стандартам на відповідному рівні, існуе ряд проблем, які гальмують розвиток автомобільного транспорту та процес евроінтеграції.

Автомобільний транспорт відіграе провідну роль, оскільки відрізняеться високою маневреністю і достатньою швидкістю доставки вантажів.

Спираючись на дані державної служби статистики України можна зробити висновок, що через тяжку ситуацію (окупацію АР Крим та тимчасово непідконтрольні Донецьку та Луганську області) в країні кількість перевезеного вантажу значно зменшилась, особливо це відобразилось на залізничному та трубопровідному транспорті.

До головних проблем міжнародних автомобільних перевезень можна віднести: забрудненість навколишнього середовища; аварійність; високі витрати; незадовільний стан дорожнього комплексу; технічний стан автомобілів; низька кваліфікація водіїв.

Окремо слід виділити вплив на перевезення вантажів автотранспортом значне подорожчання паливно-мастильних матеріалів, підвищення рівня мінімальної заробітної плати та значне зростання вартості інших матеріальних ресурсів, які впливають на формування собівартості перевезень.

Проблеми міжнародного транспорту вирішуються в різних міжнародних транспортних організаціях. Найбільше значення для розвитку міжнародних автоперевезень має робота Комітету з внутрішнього транспорту Європейської економічної комісії Організації Об'єднаних Нащій, Свропейської Конференції міністрів транспорту, Міжнародного Союзу автомобільного транспорту, Міжнародної Федерації експедиторських асоціацій, Координаційної транспортної Наради Мiністрів транспорту країн-учасниць СНД.

Шляхами вирішення проблем та покращення системи міжнародних автомобільних перевезень є: вдосконалення системи управління та контролю міжнародними перевезеннями; застосування жорсткої системи ліцензування; забезпечення якісних умов виходу на ринок; створення єдиної комплексної системи управління дорожньо-транспортною безпекою; державне фрінансування; залучення коштів страхових організацій; наявність кваліфікованих кадрів; застосування ращіональних методів перевезення.

Україна, плануючи ввійти в загальноевропейську транспортну мережу, повинна прийняти принципи Європейської загальної транспортної політики, адаптувавши їх до українських умов. Головна мета ціеї політики - утворення єдиного ринку транспортних послуг, підвищення ефрективності фрункціонування транспортних підприемств і об'єктів транспортної інфраструктури, збільшення безпеки перевезень, надійності і комфортності подорожей пасажирів і перевезень вантажів.

Досліджені проблеми автомобільного транспорту, що виникають в умовах загострення економічної ситуації в країні, потрібно враховувати при реформуванні транспортного сектору економіки. Збільшення інвестицій в галузь, вдосконалення тарифної політики, розвиток міжнародних перевезень, реалізація проектів будівництва доріг на умовах концесії, будівництво та ремонт доріг, проведення ринкових реформ - все це сприятиме ефективному розвитку автомобільної транспортної галузі. Особливо в процесі розвитку транспортного потенціалу необхідно враховувати нові умови конкурентного господарського середовища.

\section{Список літератури:}

1. Фрейдина Е.В. Исследование систем управления : учебное пособие / под ред. Ю.В. Гусева. Москва : «Омега-Л», 2008. 367 c.

2. Лащених О.А., Кузькін О.Ф., Грицай С.В. Імовірнісні і статистико-експериментальні методи аналізу транспортних процесів і систем : навч. посібник. Запоріжжя : ЗНТУ, 2009. 420 с.

3. Івченко І.Ю. Економічні ризики : навч. посібник. Київ : «Центр навчальної літератури», 2004. 304 с.

4. Кунда Н.Т., Дащенко Н.М. Конвенції та угоди у сфері міжнародних автомобільних перевезень : навч. посібник. Київ : ВД «Слово», 2010. 141 с.

5. Кунда Н.Т. Організація міжнародних автомобільних перевезень : навч. посібник. Київ : ВД «Слово», 2010. $141 \mathrm{c}$. 


\section{References:}

1. Freidyna, E.V. (2008). Yssledovanye system upravlenyia : uchebnoe posobye [Research of control systems]. Moskva : "Omeha-L». (in Russian)

2. Lashchenykh, O.A., Kuzkin, O.F., \& Hrytsai, S.V. (2009). Imovirnisni i statystyko-eksperymentalni metody analizu transportnykh protsesiv $i$ system [Likelihood and statistical-experimental methods of analysis of transport processes and systems]. Zaporizhzhia : ZNTU. (in Ukrainian)

3. Ivchenko, I.Iu. (2004). Ekonomichni ryzyky [Economic risks]. Kyiv : «Tsentr navchalnoi literatury». (in Ukrainian)

4. Kunda, N.T., \& Dashchenko, N.M. (2010). Konventsii ta uhody u sferi mizhnarodnykh avtomobilnykh perevezen [Conventions and agreements in the field of international road transport]. Kyiv : VD «Slovo». (in Ukrainian)

5. Kunda, N.T. (2010). Orhanizatsiia mizhnarodnykh avtomobilnykh perevezen [Conventions and agreements in the field of international road transport]. Kyiv : VD «Slovo». (in Ukrainian) 